\title{
Manajemen Pemasaran Sayuran Hidroponik di Desa Sidodadi KeCAMATAN GaRUM KabUPATEN BLitaR
}

\section{${ }^{1}$ Achmad Gilang Pamungkas Hani Putra, ${ }^{2}$ Adellia Andriani Putri, ${ }^{3}$ Alfina Damayanti, ${ }^{4}$ Wamustajabu Lukmanul Hakim, ${ }^{5}$ Wiratna Nila Salsabila ${ }^{6}$ Rachmadania Akbarita}

\author{
1,2,3,4,5,6 Matematika, Universitas Nadhlatul Ulama Blitar, Jawa Timur, Indonesia \\ email: ${ }^{1}$ pamungkas.putra79@gmail.com, ${ }^{2}$ adellandrianputri60@gmail.com, \\ 3alfinadmynt26@gmail.com, ${ }^{4}$ wamus1330@gmail.com, ${ }^{5}$ wiratnab76@gmail.com \\ ${ }^{6}$ rachmadania.akbarita@gmail.com
}

\begin{abstract}
Sidodadi Village, Garum District is a fertile area that located $18 \mathrm{KM}$ from the city. The majority of its residents work as farm laborers and sand miners. Almost all residents have yards that are left without any productive use. Natural conditions are still full of trees also cause the leaf litter that less conditioned. This is the idea for us to introduce an innovation in terms of land use and neglected organic waste, that is Hydroponic. The output of this activity is expected to be an additional economic source for local residents. In addition, it is also to make new job opportunities for local youth. The methods used are Explorative Survey, SWOT Analysis, Micro Teaching, Focus Discussing Group, Participatory Rural Appraisal and e-Mentoring. In its implementation, youth organizations is very enthusiastic. So the assistance and implementation process can run well and smoothly. The enthusiasm of the team and youth organizations in this activity succeeded in establishing two greenhouses with the installations. As well as making production and marketing designs which are the final determinants in this activity. The final result of this activity is the establishment of "Green Fresh" which is divided into production, marketing and publication divisions.
\end{abstract}

Keywords: PHP2D, Strategy, Marketing, Hydroponic.

\begin{abstract}
Abstrak. Desa Sidodadi, Kecamatan Garum merupakan wilayah subur yang terletak 18 KM dari pusat kota. Mayoritas warganya bekerja sebagai buruh tani maupun penambang pasir. Hampir seluruh warga desa ini memiliki pekarangan yang dibiarkan tanpa ada pemanfaatan yang produktif. Kondisi alam yang masih dipenuhi pohon-pohon juga menyebabkan sampah daunnya yang berserakan kurang terkondisikan. Hal inilah yang memunculkan ide bagi kami untuk memperkenalkan sebuah inovasi dalam hal pemanfaatan lahan dan sampah organik yang tak terurus, yaitu hidroponik. Luaran kegiatan ini diharapkan dapat menjadi sumber ekonomi tambahan bagi warga setempat. Selain itu juga, untuk membuka lapangan kerja baru bagi pemuda setempat. Metode yang digunakan adalah Explorative Survey, SWOT Analysis, Micro Teaching, Focus Discussing Group, Participatory Rural Apprasial dan e-Mentoring. Dalam pelaksanaannya, karang taruna sangat antusias dengan apa yang kami sampaikan. Sehingga pendampingan dan proses pelaksanaan dapat berjalan dengan baik dan lancar. Antusias tim dan karang taruna dalam kegiatan tersebut berhasil mendirikan dua greenhouse lengkap dengan instalasinya, serta membuat desain produksi dan pemasaran yang merupakan penentu akhir dalam kegiatan ini. Hasil akhir kegiatan ini adalah berdirinya Green Fresh yang terbagi dalam divisi produksi, pemasaran dan publikasi.
\end{abstract}

Kata Kunci: PHP2D, Strategi, Pemasaran, Hidroponik. 


\section{Pendahuluan}

Desa Sidodadi, Kecamatan Garum Kabupaten Blitar merupakan daerah subur yang berada di kaki Gunung Kelud. Tercatat pada tahun 2003 jumlah penduduk di Desa Sidodadi kurang lebih ada 10.256 jiwa dengan mayoritas bekerja sebagai petani. Pepohonan yang rindang dan penampakan alam yang masih terjaga, daerah ini memiliki sumber air yang melimpah, sehingga masyarakat desa tidak pernah kekurangan air bersih. Namun, potensi yang sedemikian rupa, masyarakatnya belum dapat memanfaatkan kondisi tersebut secara optimal. Perekonomian masyarakat Desa Sidodadi Kecamatan Garum Kabupaten Blitar masuk dalam kategori menengah kebawah. Persoalannya masyarakat belum mampu secara kreatif dan inovatif memanfaatkan peluang yang diberikan oleh alam. Banyaknya pemuda yang minim wawasan/pengetahuan dalam mengolah sampah - sampah yang ada mengakibatkan mereka hanya membakar ataupun menumpuk sampah tersebut di area lahan kosong. Sampah yang hanya ditimbun dan tidak diolah dapat berserakan kembali atau terbawa aliran air dan menyumbat aliran sungai saat musim hujan. Serta, banyaknya pemuda yang belum memiliki pekerjaan tetap. Padahal, jika masyarakat setempat bisa mengolah potensi alam sekitarnya dengan baik, maka dapat meningkatkan perekonomian masyarakat sekitar. Melimpahnya air juga belum dimanfaatkan dengan baik.

Mitra sasaran kami dalam pelaksanaan Program Holistik Pembinaan dan Pemberdayaan Desa (PHP2D) di desa ini adalah pemuda karang taruna. Kebanyakan dari mereka masih bekerja sebagai penambang pasir yang pendapatannya tidak menentu. Risiko dari aktivitas tambang ini juga sangat besar. Sehingga, kami ingin mengajak mereka untuk melakukan aktivitas bernilai ekonomi yang aman dan stabil.

Sebelum kami melakukan perencanaan. Kami melakukan analisis SWOT atau Kekuatan, Kelemahan, Kesempatan dan Ancaman. Berdasarkan pengamatan dan informasi yang kami dapatkan, diperoleh hasil analisis SWOT sebagai berikut:

\section{Kekuatan}

Desa ini memiliki banyak pemuda aktif yang tergabung dalam karang taruna "Pakem 8" di Desa Sidodadi dan memiliki kemampuan yang patut untuk dikembangkan. Kondisi alam yang berada di dataran tinggi.

\section{Kelemahan}

Kurangnya keterampilan pemudanya, sehingga potensi yang ada kurang dimanfaatkan dengan baik.

\section{Kesempatan}

Pemudanya antusias dengan pendatang dan sangat terbuka terhadap permasalahan desa.

\section{Ancaman}

Lokasi yang jauh dari pusat kota menjadi sebuah hambatan tersendiri dalam pelaksanaan maupun berjalannya program ini kedepannya.

Berdasarkan analisis SWOT permasalahan tersebut. Kami membuat beberapa rencana strategi dan solusi berdasarkan analisis SWOT yang ada, yaitu:

\section{Kekuatan - Kesempatan}

Pembinaan dilakukan dengan menargetkan sekitar 20 pemuda desa untuk diberikan keterampilan yang produktif dan mampu memanfaatkan potensi desa. 


\section{Kekuatan - Ancaman}

Kegiatan ini akan dilaksanakan lebih dari 2 kali setiap bulan untuk memberikan pelatihan keterampilan dan pendampingan yang dibutuhkan dalam proses pelaksanaan. Pelaksanaan dan prosesnya akan dilakukan sepenuhnya oleh pemuda desa tersebut.

\section{Kelemahan - Kesempatan}

Pendampingan dan pemberdayaan pemuda desa akan difokuskan dalam peningkatan keterampilan menggunakan metodemetode yang tepat.

\section{Kelemahan - Ancaman}

Bersama mitra, kami membuat sebuah desain pemasaran dan penjualan yang dapat menekan biaya perjalanan. Selain itu, pengoptimalan media internet digunakan untuk mempublikasikan kegiatan produksi dan iklan.

Dari kondisi tersebut, kami memberikan sebuah solusi yang inovatif. Kami mengajak para pemuda bersama sama membangun sebuah instalasi untuk membudidayakan sayuran dengan sistem hidroponik. Hidroponik merupakan sistem pertanian dengan menggunakan air sebagai pengganti tanah yang merupakan media serap nutrisi. Singkatnya pemberian nutrisi pada penanaman sayuran hidroponik dilarutkan pada air lalu dialirkan ke akar tanaman.

Beberapa kelebihan yang terdapat dalam budidaya tanaman secara hidroponik diantaranya adalah tidak menggunakan media tanah untuk bercocok tanam, dapat dilakukan di lahan sempit karena jarak antar tanaman dapat lebih dekat tanpa harus mengurangi risiko serangan patogen yang biasanya terdapat dalam tanah, mencegah tumbuhnya gulma yang dapat mengurangi jatah tanaman akan hara dan pemakaian pupuk yang dibutuhkan dapat dihitung lebih cermat sebanyak yang benar benar dibutuhkan oleh tanaman (Soesono, 1991; Anonim, 1992).

Nutrisi yang diberikan sudah diukur sesuai kebutuhan, sehingga kebutuhan tanaman terpenuhi secara optimal tanpa adanya kelebihan atau nutrisi yang terbuang. Sistem hidroponik ini dapat diterapkan di lahan sempit sekalipun. Membuat media tanam hidroponik juga tidaklah sulit dan tidak memakan tempat. Perawatannya pun sangat mudah. Hal ini cocok sebagai usaha maupun sekedar hobi.

Keunggulan sistem hidroponik (Masduki, 2018):

1. Tanaman mudah diperbaharui tanpa tergantung kondisi lahan dan musim.

2. Pertumbuhan dan kualitas panen dapat diatur.

3. Hemat tenaga kerja.

4. Produk bersih dan lebih higienis.

5. Hemat air dan pupuk (aman untuk kelestarian lingkungan).

6. Masa tanam lebih singkat.

7. Biaya operasional murah. Usaha budidaya sayuran hidroponik ini dipilih karena dinilai memiliki tingkat profit yang lebih tinggi daripada budidaya lainnya. Sayur hidroponik tergolong hasil produk menengah ke atas. Dengan kualitas dan manfaat yang sedemikian rupa mampu meningkatkan nilai ekonominya hingga $3 x$ lipat bahkan lebih. Sehingga diharapkan dapat meningkatkan ekonomi masyarakat dengan efisien.

Tentu usaha budidaya saja tidak akan membuahkan hasil jika tidak diimbangi dengan strategi pemasaran yang tepat sasaran. Penjualan produk hidroponik harus menjaga keseimbangan harga. Sayur hidroponik tergolong hasil produk menengah keatas. Jika dibandingkan dengan harga sayur konvensional, harga sayur hidroponik tidak mampu dijangkau semua golongan termasuk beberapa masyarakat setempat. 
Kualitas dan manfaat yang sedemikian rupa mampu meningkatkan nilai ekonomisnya hingga tiga kali lipat bahkan lebih. Sehingga, banyak produsen yang berlomba - lomba untuk dapat menguasai pasar penjualan produk hidroponik. Penguasaan pasar ditentukan dengan seberapa besar produsen tersebut mampu menawarkan produknya kepada pasar. Hal ini perlu adanya strategi yang matang untuk mampu memproduksi sebesar - besarnya dengan lahan yang seminim mungkin.

Setelah melakukan kunjungan kepada beberapa petani yang sudah berkiprah, serta melakukan diskusi bersama masyarakat. Maka, diperoleh pemecahan masalah. Dewasa kini, pemasaran sudah banyak yang dilakukan secara digital. Media sosial sudah tebukti ampuh sebagai lahan bisnis, terutama bagi kaum muda yang melek teknologi (Permana and Cendana, 2019). Hal ini tentu perlu dikembangkan di kalangan pemuda masa kini. Dimana era digital dan teknologi sudah menjadi aktivitas sehari - hari.

Hal ini memacu untuk membuat beberapa akun media sosial yang ramai pengguna seperti Instagram, Facebook dan Whatsapp (Arisandi, 2018). Media sosial tersebut akan digunakan sebagai share dan posting konten mengenai produk yang ditawarkan. Akun media sosial tersebut akan digunakan pula sebagai sarana komunikasi dan layanan konsumen secara langsung.

Kemampuan pengusaha atau wirausahawan dalam memenangkan pasar dan memperoleh keuntungan yang besar harus didukung dengan strategi pemasaran yang diterapkan. Strategi pemasaran dibentuk berdasarkan kemampuan yang dimiliki perusahaan dan dihubungkan dengan posisi perusahaan dalam persaingan. Sehingga, diperlukan adanya keberlanjutan dan manajemen yang baik oleh pemuda karang taruna sebagai pengelola budidaya. Kami dari tim PHP2D juga akan tetap memberikan pendampingan dan masukan yang bersifat membangun sebagai tindakan keberlanjutan program.

Pendampingan kami lakukan secara virtual mengingat kondisi yang kurang memungkinkan untuk bertemu secara langsung. Terkecuali pada momen tertentu. Seperti ketika menunjukkan penggunaan suatu alat, pengarahan yang bersifat praktik. Diharapkan mereka mampu menggerakkan budidaya sendiri secara matang dan siap.

\section{Metode Ilmiah}

Program ini dikembangkan melalui kerjasama dengan Karang Taruna Desa Sidodadi untuk mengolah sampah organik dan pembudidayaan sayuran hidroponik. Selain dari Karang Taruna, masyarakat setempat juga berpartisipasi dengan adanya program ini, sehingga akan terbentuk masyarakat yang mampu menerapkan pembudidayaan sayuran dengan sistem hidroponik di rumah masing-masing.

Metode yang digunakan dalam pelaksanaan Program Holistik Pembinaan dan Pemberdayaan Desa di dusun Kemloko 8, desa Sidodadi Kecamatan Garum ini adalah Explorative Survey, Micro Teaching, Focus Discussing Group (FGD), Participatory Rural Apprasial (PRA) dan -Mentoring.

Program ini merupakan hibah dari Kemdikbud yang diberikan kepada organisasi mahasiswa yang lolos pendanaan setelah mengajukan proposal. Dalam perencanaannya, kami melakukan pencarian informasi mengenai lokasi target dan kondisi di wilayah tersebut menggunakan Explorative survey. Explorative survey atau survey eksploratif adalah mencari informasi awal yang masih belum jelas. Hasil pencarian informasi ini kami mendapatkan lokasi yang sesuai dengan 
kriteria dan potensial untuk dilakukan pembinaan dan pemberdayaan masyarakatnya.

Selanjutnya, mengenai metode yang digunakan dalam melaksanakan program. Micro Teaching adalah penjelasan atau pemaparan singkat mengenai kegiatan yang akan dilaksanakan. Metode ini kami sampaikan ketika sosialisasi pembukaan, briefing sebelum memulai kegiatan, serta menjelaskan konsep kami kepada mereka. Selain memberikan penjelasan kepada mitra, micro teaching ini dinilai lebih efektif untuk meningkatkan hubungan antar tim dengan kelompok mitra. Dengan micro teaching mereka dapat memberikan argumen mereka tentang apa yang kami sampaikan. Sehingga kesatuan visi dan tujuan dapat tercapai. Setelah penjelasan diperoleh, barulah dilakukan FGD bersama masyarakat.

Focus Discussing Group (FGD) digunakan untuk mencari tahu serta menganalisis permasalahan yang terjadi pada masyarakat serta membuat gambaran dalam pelaksanaannya. (Hennink, 2013). Perencanaan dapat meminimalisir kesalahan dalam pelaksanaan kegiatan maupun adanya hambatan. Peran masyarakat disini sebagai pihak lokal yang lebih mengetahui keadaan serta kebutuhan dalam program kegiatan yang akan dijalankan, sedangkan tim PHP2D berperan sebagai pemenuhan kebutuhan sarana dan prasarana yang dibutuhkan. Sarana dan prasana yang dibeli tersebut sebagai realisasi dari dana hibah yang diberikan.

Participatory Rural Apprasial (PRA) adalah melibatkan masyarakat secara langsung dalam pelaksanaan kegiatan. Kegiatan PHP2D ini diwujudkan dalam sosialisasi, pelatihan, pendampingan, serta evaluasi keberlangsungan kegiatan. Peran tim pada metode ini yaitu sebagai pengarah serta pendamping mitra dalam pelatihan. Program ini diharapkan mampu dilaksanakan oleh mitra secara mandiri, sehingga terjadi keberlanjutan program untuk bisa mencapai target yang diinginkan.

Dalam pelaksanaannya, dibentuk beberapa divisi yang bergerak sesuai bidang garapnya masing-masing. Diantaranya: divisi produksi yang bertugas melakukan penanaman dan perawatan hingga panen. Divisi pemasaran bertugas membuat perencanaan strategi dan menjalin kerjasama untuk menawarkan hasil budidaya. Serta, divisi publikasi yang bertugas membuat konten dan melakukan aktivitas branding dan edukasi baik secara digital melalui internet maupun secara langsung kepada masyarakat. Divisi-divisi tersebut akan diisi oleh para anggota karang taruna dan akan didampingi oleh tim PHP2D sebagai fasilitator dan pemberi materi keterampilan yang diperlukan.

Selain itu, sebagai usaha keberlanjutan program ini, kami menggunakan sistem e-Mentoring. $E$ mentoring adalah pendampingan program dan usaha yang kami laksanakan secara tidak langsung (Ensher and Murphy, 2007). Hal ini karena kondisi pandemi yang sedang terjadi sehingga tidak memungkinkan kami untuk memantau dan memberikan arahan secara langsung. Namun, sebagai monitoring dan evaluasi, kami juga datang secara langsung ke lokasi untuk memastikan program berjalan dengan sesuai. Tahap monitoring dilakukan agar proses keberlanjutan oleh Tim Pengelola dari masyarakat terus berjalan. Tim Pengelola tentunya masih membutuhkan pembimbingan dalam proses pelaksanaan program. Dengan demikian tujuan dari tahap monitoring adalah sebagai berikut:

1. Melihat perkembangan program yang telah dilaksanakan. 
2. Mengetahui kendala yang ada dalam proses pelaksanaan program.

3. Mencari solusi terhadap masalah yang ada, sehingga program Desa Binaan yang dilaksanakan benar-benar efektif dan maksimal serta bersinergis.

\section{Hasil dan Pembahasan}

Program ini kami awali dengan melakukan sosialisasi dan pembukaan yang dihadiri oleh perangkat Desa Sidodadi, Rektor Universitas Nahdlatul Ulama Blitar, dosen pembimbing, Ketua Program Studi Matematika, serta seluruh anggota karang taruna. Dalam pembukaan tersebut, kepala desa Sidodadi berharap program ini akan membawa perubahan yang mampu meningkatkan kreativitas pemudanya.

Program berjalan dengan melakukan briefing dan pemaparan logbook kerja. Hal ini dilakukan agar satu pemahaman dalam melaksanakan pengerjaan. Selain itu, forum ini juga melakukan pembagian tugas dan rencana agar kegiatan dapat terorganisir dengan baik. Para pamuda karang taruna sangat aktif dan antusias dalam mengikuti forum ini, sehingga dalam hari yang sama, dapat langsung eksekusi perencanaan dan pembangunan rangka greenhouse.

Setiap melakukan perencanaan dan eksekusi, kami melakukan sedikit pemberian pemahaman tentang konsep dari hidroponik ini (micro teaching). Hal ini dilakukan untuk menjaga supaya hasil yang direncanakan dapat tercapai. Selain itu, dengan metode tersebut mereka dapat mengetahui dan memahami tanpa merasa digurui. Kami tetap menjaga hubungan antara tim dengan karang taruna selayaknya dengan kawan sendiri, supaya tidak ada canggung dan suasana tetap cair.

Tahap dua rangkaian program adalah melakukan perakitan instalasi hidroponik. Kami melakukan konsultasi dengan seorang petani hidroponik yang sudah lama berkiprah di pembudidayaan hidroponik. Instalasi yang disarankan untuk kami gunakan adalah DFT atau Deep flow Technique. Jenis instalasi ini mudah dilakukan, orang awam sekalipun dalam hidroponik.

Dalam tahap yang sama, kami juga melakukan pengolahan sampah organik untuk dibuat menjadi pupuk organik serta media tanam hidroponik ini. Pengolahan ini dilakukan dengan melakukan pencacahan pada sampah kemudian diberikan probiotik sebagai starter fermentasi. Proses fermentasi berlangsung selama 14 hari untuk mendapatkan hasil yang terbaik. Setelah siap, media tanam tersebut digunakan sebagai pengganti rockwool. Permintaan rockwool yang semakin tinggi, menyebabkan harganya semakin naik pula. Sehingga meningkatkan biaya tanam. Penggunaan media tanam dari fermentasi sampah organik tersebut dapat mengurangi biaya tanam.

Hasil perbandingan biaya tanam antara menggunakan rockwool dengan media tanam fermentasi sampah organik adalah sebagai berikut.

1. Untuk tanam per 1000 lubang, dibutuhkan rockwool sebanyak 1 slab seharga Rp. 80.000.

2. Untuk tanam per 1000 lubang, dibutuhkan media tanam fermentasi sampah organik sebanyak $15 \mathrm{~kg}$. Dengan biaya pembuatan tersebut adalah $\mathrm{Rp}$. 25.000 


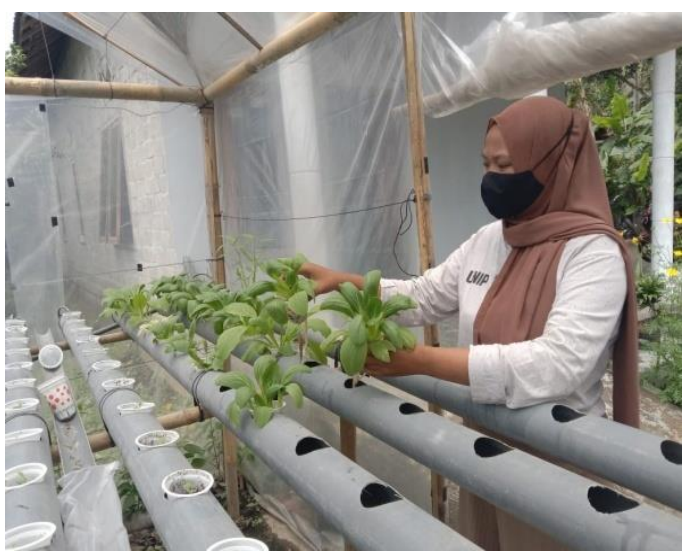

Gambar 1. Penanaman dan perawatan sayuran

Dalam aspek kapilaritasnya, fermentasi sampah ini juga sangat baik. Teksturnya menyerupai cocopeat, namun tidak terlarut dalam air. Pemakaian media hasil fermentasi sampah tidak akan mengotori saluran air. Karakteristiknya menyimpan air, sehingga tidak perlu dikhawatirkan tanaman layu ketika air tidak mengalir saat pompa tidak bekerja (mati listrik).

Lama penanaman sayuran hidroponik hingga panen relatif lebih cepat dibandingkan menggunakan rockwool. Hasil nya lebih baik karena tekstur media tanam yang mudah terurai memudahkan akar untuk tumbuh dan mencapai larutan nutrisi dengan optimal.
Penggunaan media ini juga tidak menyisakan residu sama sekali karena media bekas setelah panen dapat digunakan sebagai pupuk tanah maupun digunakan kembali. Sedangkan, rockwool hanya sekali pakai saja.

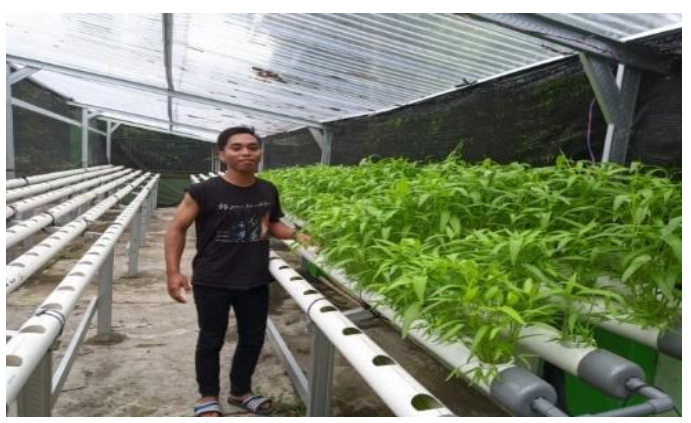

Gambar 2. Tampak sayuran siap panen

Setelah berumur 24 HST (Hari Setelah Tanam) sayuran sudah siap untuk dipanen dan dipasarkan. Namun sebelum melakukan pemasaran, kami melakukan analisis SWOT dan pasar terlebih dahulu. Analisis dilakukan oleh divisi pemasaran beserta karang taruna. Analisis ini bertujuan menemukan strategi yang tepat dalam melakukan pemasaran dan penjualan, serta menentukan target yang tepat. Hasil analisisnya sebagai berikut:

Tabel 1.

Analisis Pasar

\begin{tabular}{|c|c|c|c|}
\hline \multirow{2}{*}{\multicolumn{2}{|c|}{ HASIL ANALISIS }} & Strength & Weakness \\
\hline & & $\begin{array}{l}\text { Sayur yang ditawarkan } \\
\text { bebas bahan berbahaya } \\
\text { dan memiliki banyak } \\
\text { varian }\end{array}$ & $\begin{array}{l}\text { Terkendala akses jalur } \\
\text { dari lokasi menuju pasar } \\
\text { dan konsumen sulit }\end{array}$ \\
\hline \multirow[t]{2}{*}{ Opportunity } & \multirow{2}{*}{$\begin{array}{l}\text { Tidak ada pesaing yang } \\
\text { menggunakan hidroponik }\end{array}$} & Strategi OS & Strategi OW \\
\hline & & $\begin{array}{lr}\text { Gencar } & \text { melakukan } \\
\text { perluasan } & \text { areal } \\
\text { pemasaran, baik } & \text { kepada } \\
\text { masyarakat maupun toko } \\
\text { dan rumah makan }\end{array}$ & 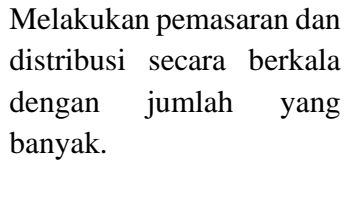 \\
\hline \multirow[t]{2}{*}{ Threat } & \multirow{2}{*}{$\begin{array}{l}\text { Konsumen pedesaan } \\
\text { belum mengenal tentang }\end{array}$} & Strategi TS & Strategi TW \\
\hline & & $\begin{array}{lr}\begin{array}{l}\text { Menawarkan } \\
\text { kepada }\end{array} & \text { sayuran } \\
\text { khalayak }\end{array}$ & $\begin{array}{l}\text { Melakukan pemasaran } \\
\text { sekaligus edukasi kepada }\end{array}$ \\
\hline
\end{tabular}




\begin{tabular}{|l|l|l|l|}
\hline $\begin{array}{l}\text { kelebihan sayuran } \\
\text { hidroponik }\end{array}$ & $\begin{array}{l}\text { perkotaan mang } \\
\text { mengetahui } \\
\text { sayuran hidroponik }\end{array}$ & $\begin{array}{l}\text { masyarakat melalui } \\
\text { konten media sosial yang } \\
\text { menarik }\end{array}$ \\
\hline
\end{tabular}

Setelah menemukan analisis SWOT untuk melakukan pemasaran, perlu dibuat segmentasi pelanggan, targeting dan positioning dari usaha. Supaya dapat menentukan target yang tepat dalam pemasaran produk, serta biaya pemasaran dan tenaga yang dibutuhkan dalam memasarkan produk dapat lebih efisien.

Hasil dari pengamatan dan diskusi bersama mitra berhasil menetapkan beberapa target yang tepat. Target pasar tersebut memenuhi segmentasi yang diperlukan. Segmentasi utama tersebut adalah:

1. Berdomisili di Kec. Garum dan sekitarnya, serta Kota Blitar

2. Perempuan berusia $16-50$ tahun

3. Bekerja sebagai ibu rumah tangga, karyawan, pegawai negeri, dan eks-TKI

4. Memiliki tingkat ekonomi menengah ke atas.

Selain dari segmentasi utama tersebut kami golongkan sebagai target pasar sekunder. Target pasar utama tersebut kami tetapkan dengan beberapa pertimbangan. Diantaranya, mayoritas perempuan pada umur tersebut memiliki tugas dan kewajiban sebagai penyedia makanan untuk keluarga sehari-hari. Tentu masyarakat selalu mengonsumsi sayuran setiap hari. Para perempuan juga menjadi kunci dalam pemasaran produk ini. Selain itu, kesadaran dan kepahaman lingkungan sosial mereka mengenai sayuran yang bersih dan higienis membuat mereka akan mencari sayuran yang higienis seperti hidroponik kami.

Segmentasi wilayah domisili dibatasi pada wilayah Kec. Garum dan sekitarnya serta wilayah Kota Blitar. Hal ini untuk menekan biaya distribusi. Biaya distribusi cukup berpengaruh pada harga produk ketika sampai ke tangan konsumen. Kami menghindari adanya gagal penjualan. Sayur juga tidak bisa bertahan lama ketika didistribusikan secara konvensional dalam jarak yang jauh.

Dalam pemasarannya, dilakukan beberapa strategi. Strategi pertama, yaitu melakukan penawaran secara langsung kepada konsumen maupun via alat komunikasi kepada target yang didapatkan dari analisis STP. Namun, strategi ini tidak berjalan cukup baik. Produk yang terjual tidak sebanding dengan yang ditawarkan, sehingga mengalami gagal penjualan.

Selanjutnya, kami mencoba melakukan lobby ke beberapa rumah makan, toko sayuran, hingga minimarket. Toko yang menjadi target adalah toko yang khusus menjual sayuran ataupun toko yang konsumennya adalah kalangan menengah ke atas. Kerjasama dengan toko sangat memudahkan dan mengurangi tenaga pemasaran. Produk dapat ditawarkan dan terjadi transaksi tanpa perlu adanya kontak secara langsung dari tim kepada calon konsumen. Peran tim pemasaran adalah memastikan bahwa produk tetap mencukupi kebutuhan pasar.

Ada beberapa yang perlu diperhatikan ketika menjalin kerjasama dengan toko, yaitu keberlanjutan stok dan menjaga kualitas. Rata - rata tiap toko dapat menjual 6 - $10 \mathrm{~kg}$ per minggu. Sehingga tuntutan ketersediaan produk adalah $25-50 \mathrm{~kg}$ per bulannya. Jika menggunakan sistem sekali panen, maka hal tersebut bukanlah sebuah masalah bagi divisi produksi. Namun, ketersediaan stok setiap harinya yang perlu diperhitungkan desain produksinya. 
Dibuatlah desain penanaman secara bertahap agar dapat dilakukan panen secara berkala. Hal ini mampu menjaga ketersediaan barang untuk memenuhi permintaan pasar. Misal dari 1000 lubang akan didesain untuk dapat panen 5 hari sekali dengan umur panen 25 HST (hari setelah tanam). Maka, 1000 dibagi 5 (hari) didapat 200 lubang sekali tanam. Sehingga dilakukan penanaman 200 lubang tiap 5 hari dan seterusnya. Nantinya ketika hari ke-25, akan dilakukan pemanenan untuk benih yang periode pertama lalu langsung ditanam kembali benih baru. Hal ini sukses menjadi solusi permasalahan tersebut.

Sebagai pendukung, dibuat juga strategi kedua, yaitu dengan menggunakan media sosial sebagai media branding dan pemasaran. Branding ini sangat penting guna memperkenalkan produk kita kepada masyarakat. Menggunakan penerapan desain dan algoritma yang tepat dapat mempercepat produk dikenal. Hal ini tentu saja sebagai usaha untuk menjangkau khalayak ramai untuk membeli produk yang ditawarkan.

Laju branding yang dapat dicapai ketika menggunakan media sosial sangat efektif daripada hanya menggunakan sistem dari mulut ke mulut atau pun menitipkan pada toko. Mempromosikan produk secara menarik dengan diselingi beberapa konten tentang keunggulan maupun kelebihan dari sayuran hidroponik. Hal ini cukup mendapat respon baik dikalangan anak muda.

Untuk sistem pembelian, digunakan konsep on the place buying atau pembelian ditempat serta Cash on Delivery (COD) atau antar dan bayar di rumah. Kedua konsep tersebut digunakan untuk memenuhi keinginan dan kebutuhan konsumen. COD juga digunakan untuk mengurangi keramaian dikala pemberlakuan kebijakan pemerintah menganai pembatasan fisik masa pandemi.

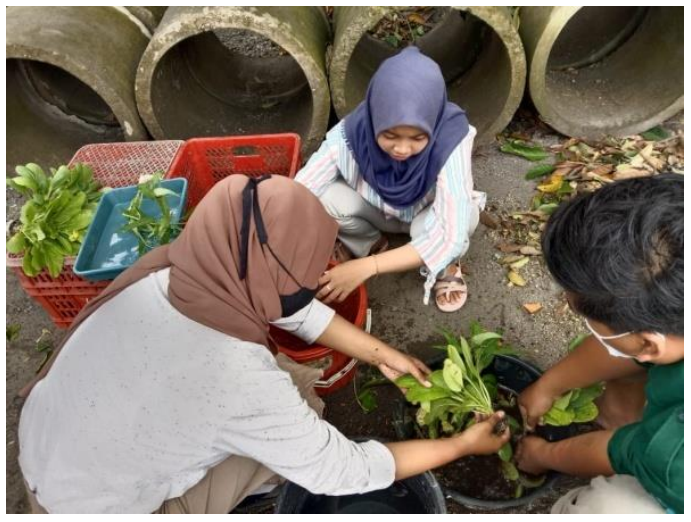

Gambar 3. Proses panen sayuran

Setelah dipanen, sayuran cukup dibersihkan dan dirapikan akarnya, namun tidak dipotong habis. Hal ini untuk menjaga kesegaran dengan akarnya yang masih lembab. Lalu pengemasan menggunakan plastik transparan yang tertutup bagian bawahnya (akar) dan terbuka bagian atasnya. Hal ini dilakukan untuk memberikan sirkulasi udara yang baik pada produk, sehingga tidak terjadi peningkatan suhu dalam kemasan yang menyebabkan sayuran menjadi layu.

Sayuran hidroponik dikemas dalam berat 250 gram. Sayuran dikemas menggunakan plastik transparan yang sedikit longgar, sehingga tidak terlalu padat untuk menghindari kerusakan daun maupun batang. Setelah dikemas rapi, produk dapat diberikan label stiker atau pun segel sebagai pengenal atau branding. Hal ini penting sebagai jaminan kualitas yang ditawarkan.

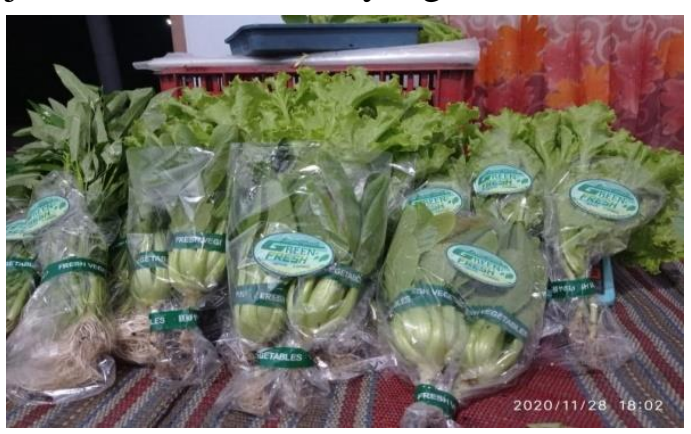

Gambar 4. Sayur Hidroponik siap dipasarkan 
Produk sayuran hidroponik yang dikemas dengan baik menambah daya jual, terutama dalam hal keamanan, kebersihan yang terjaga serta kualitas produk selama masa penyimpanan. Para konsumen sayuran sangat teliti dalam memilih sayuran yang berkualitas, sehingga mereka akan mencari merk produsen sayuran yang sudah terpercaya. Hal itulah yang membuat label dalam proses pengemasan produk sangatlah penting. Saat produk dipasarkan kemungkinan akan lebih banyak saingan dengan produk yang sama.

Saat kami melakukan wawancara kepada salah satu warga yang bertempat tinggal di Desa Sidodadi dan pernah membeli sayuran hidroponik yang kami budidaya. Warga tersebut mengaku bahwa sangat mengapresiasi produk ini. Segi tampilan produk menarik dan sayuran pun lebih tahan lama segar. Rasanya pun berbeda dengan sayuran yang biasa dijual dipasaran. Sayuran ini juga bebas dari pestisida, jadi aman untuk di konsumsi jangka panjang oleh masyarakat.

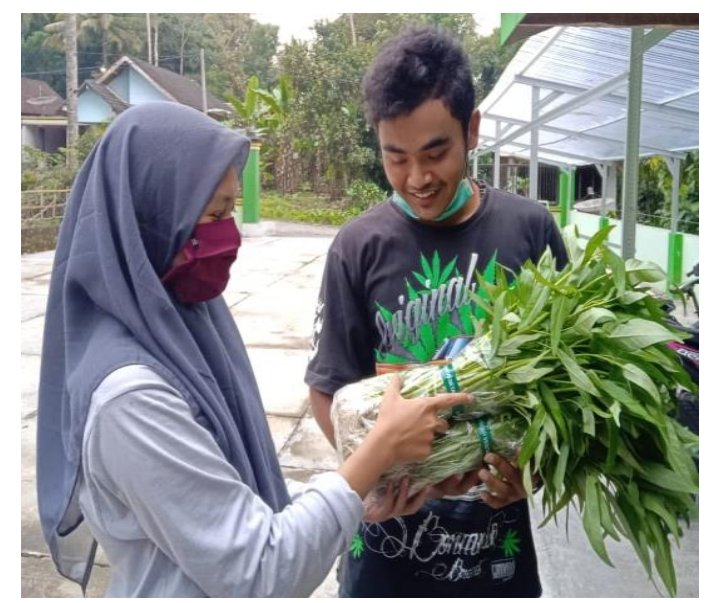

Gambar 5. Pemasaran dengan metode on the place. Konsumen beli dan datang ke kebun.

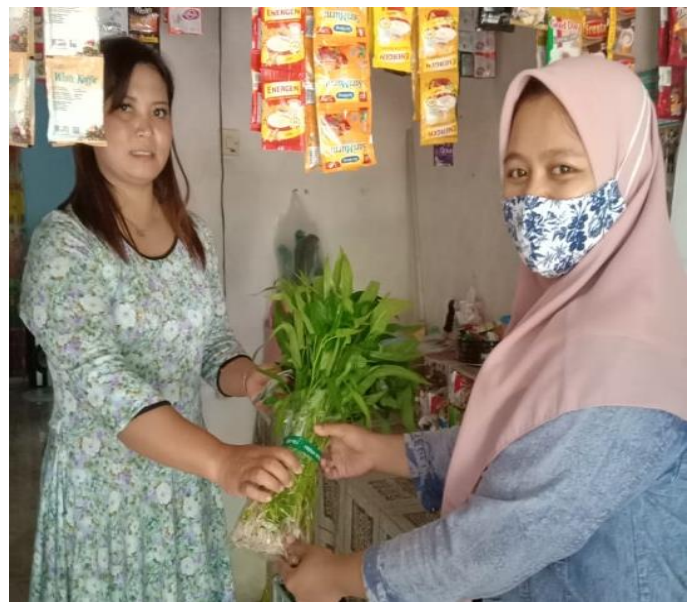

Gambar 6. Pemasaran dengan metode Cash on Delivery sesuai pesanan konsumen.

\section{Kesimpulan dan Saran}

Kegiatan ini memberikan keterampilan kepada mitra, diantaranya adalah keterampilan budidaya sayuran hidroponik, perawatan, serta pemasarannya. Upaya pengoptimalan pekarangan dengan budidaya tanaman secara hidroponik merupakan alternatif yang baik dengan banyak keunggulan serta keuntungannya. Diantaranya dapat menghasilkan tanaman dengan kuantitas dan kualitas tinggi dengan mudah, praktis, dan sederhana serta dapat dilakukan oleh semua masyarakat. Sayur yang lebih bersih dan sehat menjadi keunggulan dari hasil sayuran hidroponik.

Metode pelaksanaan program yang digunakan dalam Program Holistik Pembinaan dan Pemberdayaan Desa adalah Explorative Survey, Micro Teaching, Focus Discussing Group, Participatory Rural Apprasial dan eMentoring.

Pelatihan pembuatan greenhouse, instalasi hidroponik serta budidayanya sangat diterima oleh masyarakat. Antusias para pemuda karang taruna serta dukungan dari pihak desa sangat membantu berjalannya program ini. Para pemuda desa kini 
mampu menjalankan budidaya sayuran dengan baik.

Selain itu, pelatihan penetapan Segmentasi, Targeting dan Positioning usaha sangat membantu masyarakat Kemloko 8 Desa Sidodadi ini untuk meningkatkan dan menetapkan target yang tepat dalam usaha pemasaran produk mereka. Keterampilan tersebut, dapat menyelesaikan masalah kompleks dalam proses menjalankan usaha budidaya hidroponik ini.

Kini masyarakat Desa Sidodadi lebih produktif dengan memanfaatkan pekarangan rumah mereka sebagai tempat untuk membudidayakan sayuran Hidroponik. Pemuda Desa Sidodadi juga lebih produktif dengan membudidaya sayuran Hidroponik. Antusias tim dan karang taruna dalam kegiatan tersebut berhasil mendirikan dua greenhouse lengkap dengan instalasinya. Tahap membuat desain serta manajemen produksi dan pemasaran yang merupakan penentu akhir dalam kegiatan ini. Hasil akhir kegiatan ini adalah berdirinya Green Fresh yang terbagi dalam divisi produksi, pemasaran, dan publikasi.

Kegiatan ini sangat bermanfaat bagi masyarakat. Selain mendapatkan keterampilan untuk membudidayakan sayuran hidroponik serta melakukan transaksi yang tepat, luaran kegiatan ini juga termasuk dalam menyediakan pangan sehat yang dapat diperoleh melalui pekarangan dengan sistem hidroponik. Kedepannya, program ini dapat dikembangkan dengan baik oleh masyarakat Desa Sidodadi dan mampu menghasilkan produk hidroponik yang berkualitas tinggi, bersih, menarik, dapat menyuplai secara kontinu, dan banyak peminatnya. Pemasaran dapat meluas juga dapat menyuplai ke berbagai daerah.

\section{Ucapan Terima Kasih}

Ucapan terimakasih kami haturkan kepada seluruh perangkat pemerintah Desa Sidodadi Kecamatan Garum yang sudah memberikan izin serta dukungan, Karang taruna Pemuda Kemloko 8 (PAKEM WOLU) yang bersedia menjadi mitra dalam kegiatan ini, dosen pembimbing PHP2D yang telah memberikan arahan, serta tim PHP2D Himpunan Mahasiswa Matematika Universitas Nahdlatul Ulama Blitar yang telah meluangkan 6 kali purnamanya dalam menyukseskan program ini. Kami berharap pemerintah tetap mendukung adanya program pengembangan desa serupa yang bertujuan untuk pemberdayaan masyarakat desa. Hal tersebut sangat berdampak baik pada kemajuan Indonesia di masa yang akan datang.

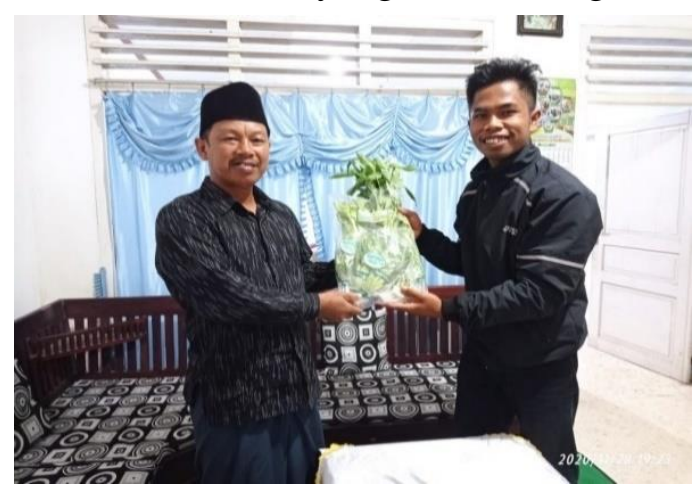

Gambar 7. Ketua tim PHP2D HIMATIKA bersama Kepala Desa Sidodadi, Garum

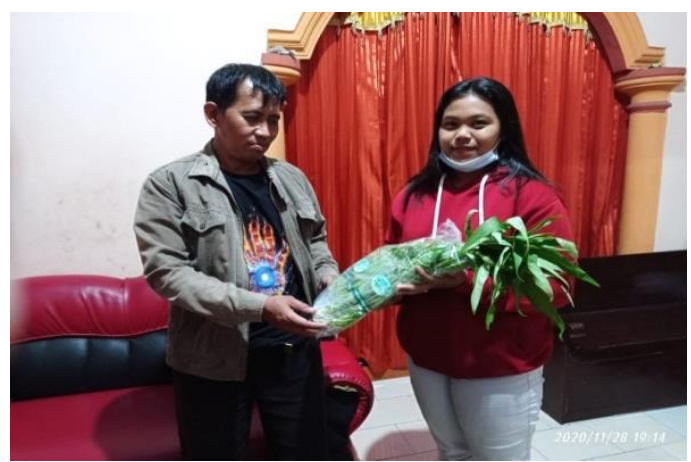

Gambar 8. Karangtaruna bersama perangkat desa Sidodadi, kecamatan Garum 


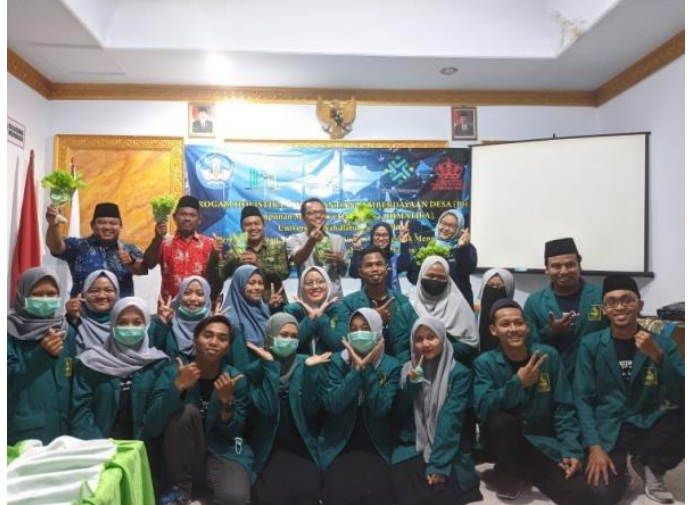

Gambar 9. Tim PHP2D bersama perangkat desa Sidodadi serta rektorat UNU Blitar dan Dosen Matematika

\section{DAFTAR PUSTAKA}

Arisandi, Y. T. (2018) 'Efektivitas penerapan e-commerce dalam perkembangan usaha kecil menengah di sentra industri sandal dan sepatu Wedoro Kabupaten Sidoarjo'. Universitas Airlangga.

Ensher, E. A. and Murphy, S. E. (2007) 'E-mentoring', The handbook of mentoring at work, pp. 299-322.

Hennink, M. M. (2013) Focus group discussions. Oxford University Press.

Masduki, A. (2018) 'Hidroponik Sebagai Sarana Pemanfaatan Lahan Sempit di Dusun Randubelang, Bangunharjo, Sewon, Bantul', Jurnal Pemberdayaan: Publikasi Hasil Pengabdian Kepada Masyarakat, 1(2), pp. 185-192.

Nurwahyuni, E. (2012) 'Optimalisasi pekarangan melalui budidaya tanaman secara hidroponik', in
Prosiding Seminar Nasional Optimalisasi Pekarangan, Semarang, pp. 863-868.

Permana, S. D. H. and Cendana, M. (2019) 'Pemanfaatan Sosial Media Sebagai Strategi Promosi Bagi Sustainability Bisnis UMKM', ETHOS: Jurnal Penelitian dan Pengabdian kepada Masyarakat, 7(2), pp. 163-169. 